\title{
Ionotropic Glutamate Receptor Modulation Preferentially Affects NMDA Receptor Expression in Rat Hippocampus
}

\author{
DANIEL J. HEALY AND JAMES H. MEADOR-WOODRUFF* \\ Mental Health Research Institute and Department of Psychiatry, University of Michigan, Ann Arbor, Michigan
}

\begin{abstract}
KEY WORDS NMDA receptor; AMPA receptor; kainate receptor; riluzole; brain
ABSTRACT Electrophysiological data suggest that alterations in the function of one glutamate receptor subtype may affect the function of other subtypes. Further, previous studies have demonstrated that NMDA receptor antagonists affect NMDA and kainate receptor expression in rat hippocampus. In order to address the mutual regulation of NMDA, AMPA, and kainate receptor expression in rat hippocampus, we conducted two experiments examining the effects of NMDA and non-NMDA glutamate receptor modulators on NMDA, AMPA, and kainate receptor expression using in situ hybridization and receptor autoradiography. NMDA receptor expression was preferentially affected by systemic treatments, as all drugs significantly altered $\left[{ }^{3} \mathrm{H}\right] \mathrm{MK}-801$ binding, and several drugs increased $\left[{ }^{3} \mathrm{H}\right]$ ifenprodil binding. GYKI52466 and aniracetam treatments resulted in changes in both $\left[{ }^{3} \mathrm{H}\right]$ ifenprodil binding and NR2B mRNA levels, consistent with the association of this subunit and binding site in vitro. There were more modest effects on AMPA and kainate receptor expression, even by direct antagonists. Together, these data suggest that ionotropic glutamate receptors interact at the level of expression. These data also suggest that drug regimens targeting one ionotropic glutamate receptor subtype may indirectly affect other subtypes, potentially producing unwanted side effects. Synapse 38:294-304, 2000. ๑ 2000 Wiley-Liss, Inc.
\end{abstract}

\section{INTRODUCTION}

Ionotropic glutamate receptors are multimeric associations of subunits that form ligand-gated ion channels and are identified by their selective agonists $\mathrm{N}$ methyl-D-aspartate (NMDA), $\alpha$-amino-3-hydroxy-5methylisoxazoleproprionic acid (AMPA), and kainate. The AMPA receptor subunits are derived from a family of four genes termed gluR1-gluR4, while kainate receptor subunits are derived from genes for the lowaffinity gluR5-gluR7 and high-affinity KA1-KA2 subunits (Hollmann and Heinemann, 1994). The NMDA receptor subunits are encoded by five genes termed NR1 and NR2A-NR2D (Hollmann and Heinemann, 1994). NR1 is expressed as one of eight isoforms, due to the alternative splicing of exons 5, 21, and 22 (Durand et al., 1993; Hollmann and Heinemann, 1994). Because subunits of the same subtype can coassemble into multiple potential combinations, there may be significant heterogeneity within a given subtype. Further, the pharmacological regulation of glutamate receptors depends on the unique combination of binding sites on the assembled receptor, which are associated with the presence of selected subunits (Hollmann and Heinemann, 1994). For example, there is a site on the NMDA receptor for the binding of glutamate, and competitive antagonists of the receptor, like CGP39653, probably compete with glutamate at this site. The presence of NR2A in the final receptor is associated with NMDA receptors, showing a greater affinity for CGP39653. A separate glycine binding site must also be occupied before glutamate can activate the ion channel and MDL105,519 is an antagonist of this site. This ligand is associated with NR1 expression. In addition, there is a site within the ion channel itself associated with the binding of noncompetitive antagonists of the NMDA receptor, such as MK-801. NMDA receptors containing NR2A or NR2B subunits show a greater affinity for MK-801 than those containing NR2C or NR2D. Finally, there is a polyamine modulatory site that is antagonized by the binding of ifenprodil, either directly or through another allosteric site, which is associated with the NR2B subunit. Assembled AMPA receptors

\footnotetext{
Contract grant sponsor: National Institute of Mental Health; Contract grant number: MH53327.

*Correspondence to: James H. Meador-Woodruff, M.D., Mental Health Research Institute, Department of Psychiatry, University of Michigan, 205 Zina Pitcher Place, Ann Arbor, MI 48109-0720. E-mail: jimmw@umich.edu

Received 30 November 1999; Accepted 8 February 2000
} 
also contain several binding sites, one for glutamate, another at which competitive antagonists such as CNQX act (through an allosteric mechanism that affects glutamate binding), and yet another where desensitization modulators exert their influence. Little is known how subunit composition affects AMPA agonist and antagonist binding. Similarly, kainate receptors contain a glutamate binding site, although other binding sites have not been as well characterized. Subunit composition represents a mechanism that may influence the functional properties of ionotropic glutamate receptors.

Electrophysiological data suggest that alterations in the function of one glutamate receptor subtype may affect the function of other subtypes. Kainate receptors appear to decrease inhibitory (GABAergic) tone (Clarke et al., 1997; Rodriguez-Moreno et al., 1997), which affects postsynaptic AMPA and NMDA receptormediated activity (He et al., 1998). Further, AMPA receptors appear to play a permissive role for NMDA receptor activity (Wheal and Thomson, 1995). NMDA receptors are blocked by magnesium ions at physiological concentrations, which is voltage-dependent. Magnesium ions are extruded from the ion channel with the partial depolarization of the cell membrane resulting from AMPA receptor activation. Therefore, it might be expected that altered activity mediated by one subtype of ionotropic glutamate receptor may result in compensatory changes in the activity of the other subtypes. These changes may include alterations in receptor composition or receptor number.

Several previous studies have demonstrated that uncompetitive NMDA receptor antagonists affect NMDA and kainate receptor expression in the hippocampus (e.g., Gao and Tamminga, 1995, 1996), but few studies have examined the effects of drugs that modulate AMPA or kainate receptors. We performed two experiments that utilized systemic treatment with NMDA, AMPA, and kainate receptor antagonists, and determined the expression of ionotropic glutamate receptors using in situ hybridization and receptor autoradiography. These techniques allow us to examine both subunit composition and binding properties of final assembled receptors. Our overall hypothesis was modulation of ionotropic glutamatergic activity via one receptor subtype would result in alterations in the expression of all three ionotropic glutamate receptors in the hippocampus.

\section{MATERIALS AND METHODS Animal treatments and preparation}

Adult, male Sprague-Dawley rats (250 gm) were housed five to a cage with food and water ad libitum. In the MK-801 experiment (Experiment 1), one set of five rats was injected s.c. with either $0.3 \mathrm{mg} / \mathrm{kg}, 1.0 \mathrm{mg} / \mathrm{kg}$, or sterile $\mathrm{H}_{2} \mathrm{O}$ vehicle for $1,2,5$, or 10 days. Animals were sacrificed $2 \mathrm{~h}$ after their last injection, their
TABLE I. Mechanism of action of the drugs used in the two experiments

\begin{tabular}{ll}
\hline Drug & \multicolumn{1}{c}{ Mechanism of action } \\
\hline MK-801 & NMDA receptor antagonist \\
Aniracetam & AMPA receptor densensitization inhibitor \\
GYKI52466 & AMPA receptor densensitization facilitator \\
NBQX & Selective competitive AMPA receptor antagonist \\
CNQX & Less selective competitive AMPA/kainate \\
& receptor antagonist \\
Riluzole & Glutamate release inhibitor \\
\hline
\end{tabular}

brains immediately removed, and frozen in isopentane. The brains were stored at $-80^{\circ} \mathrm{C}$ until sectioned. For the AMPA/kainate receptor modulator experiment (Experiment 2), groups of 10 rats were treated with 7 daily subcutaneous injections of either DMSO vehicle, aniracetam (20 mg/kg), NBQX (7 mg/kg), CNQX (10 $\mathrm{mg} / \mathrm{kg})$, GYKI 52466 (8 $\mathrm{mg} / \mathrm{kg})$, or riluzole $(4 \mathrm{mg} / \mathrm{kg})$ (Table I). Twenty-four hours after the last injection, the animals were sacrificed, their brains immediately removed, and frozen in isopentane. The brains were stored at $-80^{\circ} \mathrm{C}$ until sectioned. For both experiments, doses of ionotropic glutamate receptor modulators were chosen based on previous studies that demonstrated biochemical or behavioral changes resulting from subchronic treatment (Healy and Meador-Woodruff, 1996; Himori et al., 1995; Malgouris et al., 1989; Mead and Stephens, 1998; Romettino et al., 1991; Vanover, 1998; Wahl et al., 1993; Yamada et al., 1985).

Each brain was thawed for $30 \mathrm{~min}$ to a temperature of $-20^{\circ} \mathrm{C}$ and mounted for cryostat sectioning. Ten $\mu \mathrm{m}$ sections were obtained throughout each brain and thaw-mounted on polylysine-subbed microscope slides. The slides were dessicated and stored at $-80^{\circ} \mathrm{C}$ until used for in situ hybridization and receptor autoradiography.

\section{In situ hybridization}

Riboprobes were synthesized from linearized plasmid DNA containing subclones of these ionotropic glutamate receptor subunits, as previously described (Meador-Woodruff et al., 1997). The subclones for NMDA, AMPA, and kainate receptor subunits are summarized in Table II. Briefly, $100 \mu \mathrm{Ci}$ of $\left[{ }^{35} \mathrm{~S}\right]-\mathrm{UTP}$ was dried and $2.0 \mu \mathrm{l} 5 \times$ transcription buffer, $1.0 \mu \mathrm{l} 0.1$ M DTT, $1.0 \mu \mathrm{l}$ each of $10 \mathrm{mM}$ ATP, CTP, and GTP, 2.0 $\mu l$ linearized plasmid DNA, $0.5 \mu \mathrm{l}$ RNase inhibitor, and $1.5 \mu \mathrm{T}$ T3 or T7 RNA polymerase enzyme were added to the tube and incubated for $2 \mathrm{~h}$ at $37^{\circ} \mathrm{C}$. One $\mu \mathrm{l}$ DNase (RNase-free) was then added and the mixture was incubated for $15 \mathrm{~min}$ at room temperature. The reaction mixture was sieved through a 1 cc syringe containing G-50 Sephadex equilibrated in Tris buffer $(100 \mathrm{mM}$ Tris-HCl, pH 7.5, 12.5 mM EDTA, pH 8.0, $150 \mathrm{mM}$ $\mathrm{NaCl}$, and $0.2 \% \mathrm{SDS}$ ) and $100 \mu \mathrm{l}$ fractions were eluted.

Two slides per animal for each probe were removed from $-80^{\circ} \mathrm{C}$ storage and placed in $4 \%$ (weight:vol) formaldehyde at room temperature for $1 \mathrm{~h}$. The slides 
TABLE II. Probes used for in situ hybridization studies

\begin{tabular}{lcc}
\hline Probe & Length (bp) & Region encoded \\
\hline NR1 & 460 & exons 7-10 \\
NR2A & 668 & N-terminus \\
NR2B & 808 & N-terminus \\
NR2C & 768 & N-terminus \\
NR2D & 783 & N-terminus \\
GluR1 & 507 & N-terminus \\
GluR2 & 534 & N-terminus \\
GluR3 & 506 & N-terminus \\
GluR4 & 358 & N-terminus \\
GluR5 & 765 & N-terminus \\
GluR6 & 484 & N-terminus \\
GluR7 & 865 & N-terminus \\
KA1 & 607 & N-terminus \\
KA2 & 469 & N-terminus \\
\hline
\end{tabular}

were then washed in $2 \times \mathrm{SSC}(300 \mathrm{mM} \mathrm{NaCl} / 30 \mathrm{mM}$ sodium citrate, $\mathrm{pH}$ 7.2) three times for $5 \mathrm{~min}$ each. The slides were then washed in deionized $\mathrm{H}_{2} \mathrm{O}$ for $1 \mathrm{~min}$ before being placed in $0.1 \mathrm{M}$ triethanolamine, $\mathrm{pH}$ 8.0/ acetic anhydride, 400:1 (vol:vol), on a stir plate for 10 $\mathrm{min}$. The final wash was in $2 \times \mathrm{SSC}$ buffer for $5 \mathrm{~min}$, followed by dehydration through graded alcohols and air drying. A cover slip with $30 \mu l$ of riboprobe (1 million dpm)/75\% formamide buffer/0.01 M DTT was placed on each slide. Slides were placed in a covered tray with filter paper saturated with $75 \%$ formamide buffer and incubated at $55^{\circ} \mathrm{C}$ overnight.

The next day the coverslips were removed and the slides were placed in $2 \times \mathrm{SSC}$ for $5 \mathrm{~min}$, followed by RNase $(200 \mu \mathrm{g} / \mathrm{ml}$ in $10 \mathrm{mM}$ Tris- $\mathrm{HCl}, \mathrm{pH}$ 8.0/0.5 M $\mathrm{NaCl})$ at $37^{\circ} \mathrm{C}$ for $30 \mathrm{~min}$. The slides then underwent the following washes: $2 \times \mathrm{SSC}$ at room temperature for $10 \mathrm{~min}$; $1 \times \mathrm{SSC}$ for $10 \mathrm{~min}$ at room temperature; $0.5 \times$ $\mathrm{SSC}$ at $55^{\circ} \mathrm{C}$ for $60 \mathrm{~min}$; and $0.5 \times \mathrm{SSC}$ for $10 \mathrm{~min}$ at room temperature. The slides were dehydrated in graded ethanol solutions and air dried. They were placed in X-ray cassettes and apposed to Kodak XAR-5 film for 1-35 days.

\section{Receptor autoradiography}

The conditions used to determine binding to NMDA, AMPA, and kainate receptors are summarized below:

\section{$\left[{ }^{3} \mathrm{H}\right] \mathrm{MK}-801$ (intrachannel site of the NMDA receptor)}

The slides were thawed to room temperature and placed in $5 \mathrm{mM}$ Tris-Cl with $50 \mu \mathrm{M}$ L-glutamate, $50 \mu \mathrm{M}$ spermine, and $50 \mu \mathrm{M}$ glycine $(\mathrm{pH} 7.6)$ at $4^{\circ} \mathrm{C}$ (Huettner and Bean, 1987; Ransom and Stec, 1988). After 10 min, the slides were dipped quickly in water and air-dried using the "cool" setting of a blow dryer. The $\left[{ }^{3} \mathrm{H}\right] \mathrm{MK}-$ 801 was diluted to $3 \mathrm{nM}\left(\sim 3 \times K_{d}\right)$ using $5 \mathrm{mM}$ Tris$\mathrm{Cl} / 50 \mu \mathrm{M}$ L-glutamate $/ 50 \mu \mathrm{M}$ spermine $/ 50 \mu \mathrm{M}$ glycine buffer. For each animal, two slides were incubated with $\left[{ }^{3} \mathrm{H}\right] \mathrm{MK}-801$ to determine total binding and one slide with $\left[{ }^{3} \mathrm{H}\right] \mathrm{MK}-801$ plus $0.01 \mathrm{mM}$ unlabeled MK-801 to determine nonspecific binding. The slides were incubated for $60 \mathrm{~min}$ at room temperature. After incuba- tion, the slides were washed for 30 sec each in three $4^{\circ} \mathrm{C}$ washes of $5 \mathrm{mM}$ Tris-Cl, then quickly dipped in $4^{\circ} \mathrm{C}$ water and air-dried using the "cool" setting of a blow dryer. The slides were placed in autoradiography cassettes and apposed to Amersham $\left[{ }^{3} \mathrm{H}\right]$ Hyperfilm for 7 days.

\section{$\left[{ }^{3} \mathrm{H}\right]$ Ifenprodil (polyamine site of the NMDA receptor)}

The slides were thawed to room temperature and placed in $50 \mathrm{mM}$ Tris-Cl ( $\mathrm{pH}$ 7.4) at room temperature (Hashimoto et al., 1994). After $15 \mathrm{~min}$, the slides were dipped quickly in water and air-dried using the "cool" setting of a blow dryer. The $\left[{ }^{3} \mathrm{H}\right]$ ifenprodil was diluted to $20 \mathrm{nM}\left(\sim 3 \times K_{d}\right)$ using $50 \mathrm{mM}$ Tris-Cl with $3 \mu \mathrm{M}$ GBR-12909 (to block sigma receptors). For each subject, two slides were incubated with $\left[{ }^{3} \mathrm{H}\right]$ ifenprodil to determine total binding, and one slide with $\left[{ }^{3} \mathrm{H}\right]$ ifenprodil plus $10 \mathrm{mM}$ spermine to determine nonspecific binding. The slides were incubated for $120 \mathrm{~min}$ at $4^{\circ} \mathrm{C}$. After incubation, the slides were washed for $30 \mathrm{sec}$ each in three $4^{\circ} \mathrm{C}$ washes of $50 \mathrm{mM}$ Tris-Cl, then quickly dipped in $4^{\circ} \mathrm{C}$ water and air-dried using the "cool" setting of a blow dryer. The slides were placed in autoradiography cassettes and apposed to Amersham $\left[{ }^{3} \mathrm{H}\right]$ Hyperfilm for 2 days.

\section{$\left[{ }^{3} \mathrm{H}\right]$ CGP39653 (glutamate site of the NMDA receptor)}

The slides were thawed to room temperature and placed in $50 \mathrm{mM}$ Tris-Cl ( $\mathrm{pH}$ 8.0) at room temperature (Sills et al., 1991; White and Vogel, 1996). After 45 min, the slides were dipped quickly in water and air-dried using the "cool" setting of a blow dryer. The $\left[{ }^{3} \mathrm{H}\right]$ CGP39653 was diluted to $20 \mathrm{nM}\left(\sim 3 \times K_{d}\right)$ using $50 \mathrm{mM}$ Tris-Cl. For each animal, two slides were incubated with $\left[{ }^{3} \mathrm{H}\right] \mathrm{CGP} 39653$ to determine total binding and one slide with $\left[{ }^{3} \mathrm{H}\right] \mathrm{CGP} 39653$ plus $1 \mathrm{mM}$ glutamate to determine nonspecific binding. The slides were incubated for $45 \mathrm{~min}$ at room temperature. After incubation, the slides were washed for 1 sec each in three $4^{\circ} \mathrm{C}$ washes of $50 \mathrm{mM}$ Tris- $\mathrm{Cl}$, then quickly dipped in $4^{\circ} \mathrm{C}$ water and air-dried using the "cool" setting of a blow dryer. The slides were placed in autoradiography cassettes and apposed to Amersham $\left[{ }^{3} \mathrm{H}\right] \mathrm{Hyperfilm}$ for 2 weeks.

\section{$\left[{ }^{3} \mathrm{H}\right] \mathrm{MDL105,519}$ (glycine site of the NMDA receptor)}

The slides were thawed to room temperature and placed in $50 \mathrm{mM}$ Tris-Cl ( $\mathrm{pH}$ 6.0) at room temperature (Baron et al., 1996; Siegel et al., 1996). After $30 \mathrm{~min}$, the slides were dipped quickly in water and air-dried using the "cool" setting of a blow dryer. The $\left[{ }^{3} \mathrm{H}\right] \mathrm{MDL} 105,519$ was diluted to $12 \mathrm{nM}\left(\sim 3 \times K_{d}\right)$ using $50 \mathrm{mM}$ Tris-Cl. For each animal, two slides were incu- 
bated with $\left[{ }^{3} \mathrm{H}\right] \mathrm{MDL} 105,519$ to determine total binding and one slide with $\left[{ }^{3} \mathrm{H}\right] \mathrm{MDL} 105,519$ plus $50 \mathrm{mM}$ glycine to determine nonspecific binding. The slides were incubated for $60 \mathrm{~min}$ at room temperature. After incubation, the slides were washed for 60 sec each in three $4^{\circ} \mathrm{C}$ washes of $50 \mathrm{mM}$ Tris- $\mathrm{Cl}$, then quickly dipped in $4^{\circ} \mathrm{C}$ water and air-dried using the "cool" setting of a blow dryer. The slides were placed in autoradiography cassettes and apposed to Amersham $\left[{ }^{3} \mathrm{H}\right]$ Hyperfilm for 3 days.

\section{$\left[{ }^{3} \mathrm{H}\right]$ AMPA (glutamate site of the AMPA receptor)}

The slides were thawed to room temperature and placed in $50 \mathrm{mM}$ Tris-citrate $(\mathrm{pH} 7.4)$ at room temperature (Healy et al., 1998; Nielsen et al., 1988). After 30 min, the slides were dipped quickly in water and airdried using the "cool" setting of a blow dryer. The $\left[{ }^{3} \mathrm{H}\right] \mathrm{AMPA}$ was diluted to $18 \mathrm{nM}\left(\sim 3 \times K_{d}\right)$ using 50 $\mathrm{mM}$ Tris-citrate with $0.1 \mathrm{M}$ KSCN. For each animal, two slides were incubated with $\left[{ }^{3} \mathrm{H}\right] \mathrm{AMPA}$ to determine total binding and one slide with $\left[{ }^{3} \mathrm{H}\right]$ AMPA plus $10 \mu \mathrm{M}$ CNQX as blocker to determine nonspecific binding. The slides were incubated for $45 \mathrm{~min}$ at $4^{\circ} \mathrm{C}$. After incubation, the slides were washed for 5 sec each in three $4^{\circ} \mathrm{C}$ washes of $50 \mathrm{mM}$ Tris-citrate, then quickly dipped in $4^{\circ} \mathrm{C}$ water and air-dried using the "cool" setting of a blow dryer. The slides were placed in autoradiography cassettes and apposed to Amersham $\left[{ }^{3} \mathrm{H}\right]$ Hyperfilm for 3 weeks.

\section{$\left[{ }^{3} \mathrm{H}\right]$ Kainate (glutamate site of the kainate receptor)}

The slides were thawed to room temperature and placed in $50 \mathrm{mM}$ Tris-citrate $(\mathrm{pH} 7.4)$ at room temperature (Monaghan and Cotman, 1982). After $30 \mathrm{~min}$, the slides were dipped quickly in water and air-dried using the "cool" setting of a blow dryer. The $\left[{ }^{3} \mathrm{H}\right]$ kainate was diluted to $12 \mathrm{nM}\left(\sim 3 \times K_{d}\right)$ using $50 \mathrm{mM}$ Tris-citrate. For each animal, two slides were incubated with $\left[{ }^{3} \mathrm{H}\right]$ kainate to determine total binding and one slide with $\left[{ }^{3} \mathrm{H}\right]$ kainate plus $10 \mu \mathrm{M}$ CNQX to determine nonspecific binding. The slides were incubated for $30 \mathrm{~min}$ at $4^{\circ} \mathrm{C}$. After incubation, the slides were washed for 10 sec each in three $4^{\circ} \mathrm{C}$ washes of $50 \mathrm{mM}$ Tris-citrate, then quickly dipped in $4^{\circ} \mathrm{C}$ water and air-dried using the "cool" setting of a blow dryer. The slides were placed in autoradiography cassettes and apposed to Amersham $\left[{ }^{3} \mathrm{H}\right]$ Hyperfilm for 3 weeks.

\section{Image and data analyses}

Film was developed and used for quantitative, computer image analysis (with NIH Image 1.56), as previously described (Meador-Woodruff et al., 1997). For in situ hybridization, tissue background was subtracted from total gray scale values (GSV) for the cell body layers of dentate gyrus and CA1-CA4 and for receptor autoradiography nonspecific binding was subtracted from total binding in cellular and dendritic layers of dentate gyrus and CA1-CA4. These hippocampal regions were identified using an atlas of the rat brain (Paxinos and Watson, 1982). Left and right side values were pooled, as were values for duplicate slides, providing one averaged GSV per region per animal. The corrected average GSV was converted into optical density (OD). In Experiment 1, OD values for each probe or binding site were analyzed in Statistica 4.1 using three-way ANOVA, with treatment, duration of treatment, and region as the independent variables. Posthoc comparisons were performed using Newman-Kuels test. For several analyses, there were missing values in the 5-day treatment group; mean substitution was utilized for these missing data points prior to statistical analyses. In Experiment 2, OD values for each probe or binding site were analyzed in Statview 4.01 using twoway ANOVA, with treatment and region as the independent variables. Post-hoc comparisons were performed using the Scheffe test.

\section{RESULTS}

All NMDA, AMPA, and kainate receptor subunit mRNAs were detected in the hippocampal formation (Figs. 1, 2), except NR2C mRNA, which was not consistently expressed above background levels under conditions used for these experiments; this is in agreement with previous work (Wheal and Thomson, 1995; Meador-Woodruff et al., 1997). Similarly, the six binding sites were visualized in hippocampal formation (Figs. $1,2)$.

\section{Experiment 1 (MK-801 time course) NMDA receptor regulation}

There was no main effect for treatment on any of the four subunit mRNAs (Fig. 3). There was a main effect for duration of treatment for NR2B $\left(\mathrm{F}_{3,21}=3.47 ; P<\right.$ 0.05). Post-hoc analysis revealed that values from 10 days of treatment differed significantly from the other three treatment times (all $P<0.05$ ). There were significant treatment by duration interactions for both NR2A $\left(\mathrm{F}_{6,36}=2.65 ; P<0.05\right)$ and NR2B $\left(\mathrm{F}_{6,36}=2.59\right.$; $P<0.05$ ); however, there were no significant differences between treatments and controls for the same duration of treatment. There were several significant findings for NMDA receptor binding sites in this experiment (Fig. 4). $\left[{ }^{3} \mathrm{H}\right] \mathrm{MK}-801$ binding was significantly decreased by MK-801 treatment $\left(\mathrm{F}_{2,12}=54.75 ; P<\right.$ 0.0001). Post-hoc tests demonstrated that both doses of MK-801 differed from control (both $P<0.001$ ), as well as from each other $(P<0.05)$. There was a main effect for treatment on $\left[{ }^{3} \mathrm{H}\right]$ ifenprodil binding $\left(\mathrm{F}_{2,12}=10.21\right.$; $P<0.005$ ), with low dose MK-801 treatment significantly differing from high dose and control (both $P<$ 

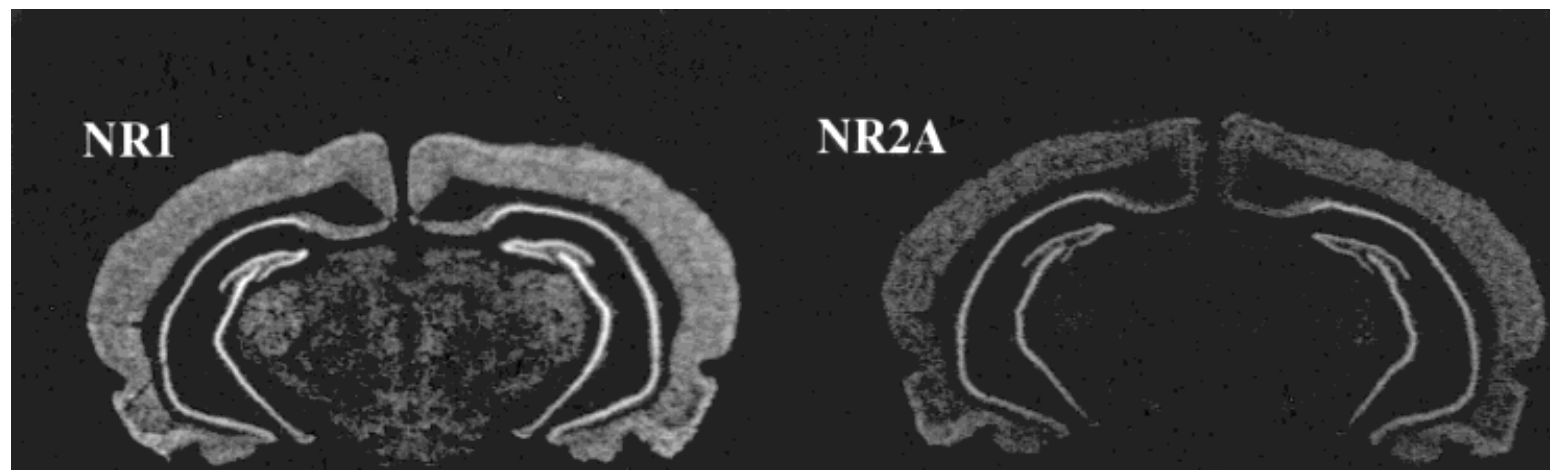

NR2B

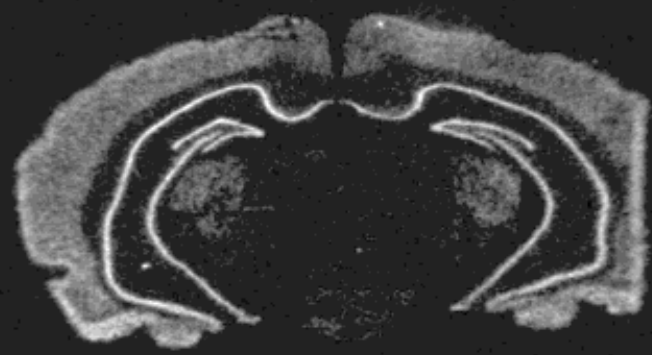

[3]HDL105519

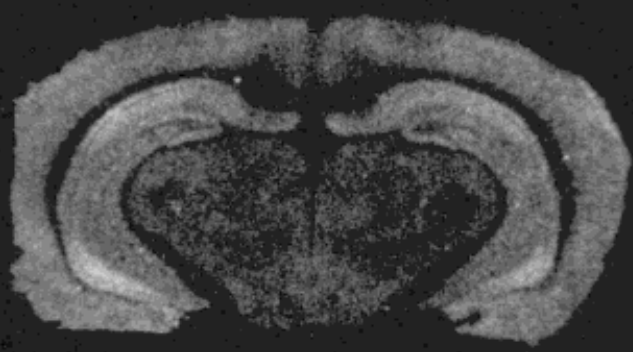

\section{$[3]$ ifenprodil}

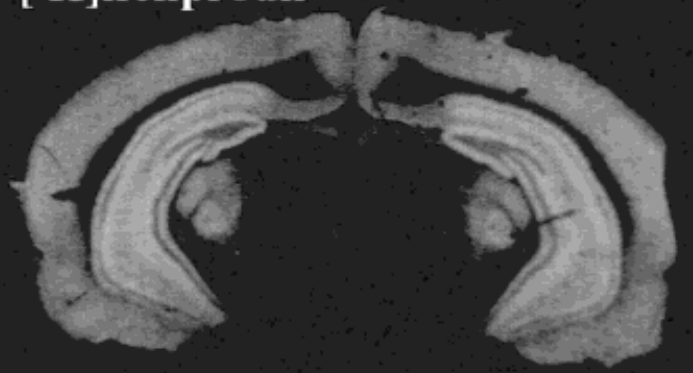

NR2D

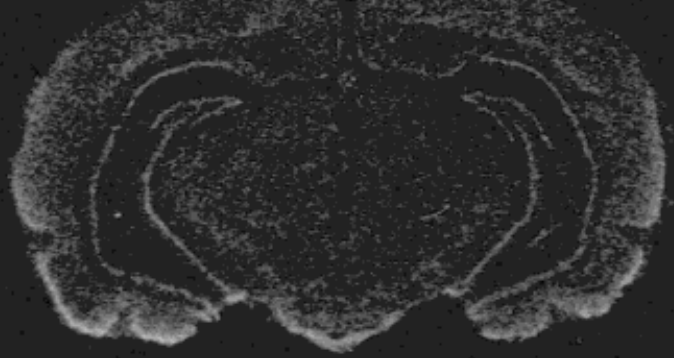

[3H]CGP39653

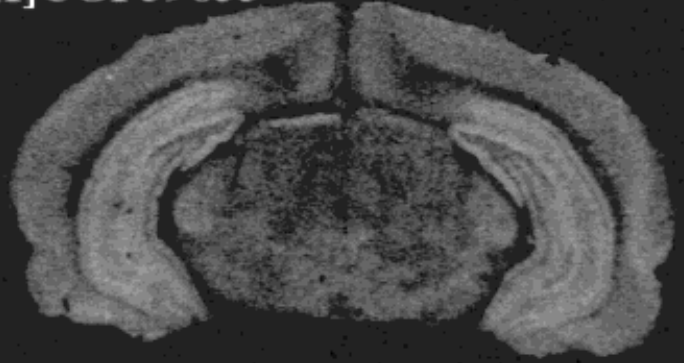

$\left[{ }^{3} \mathrm{H}\right] \mathrm{MK}-801$

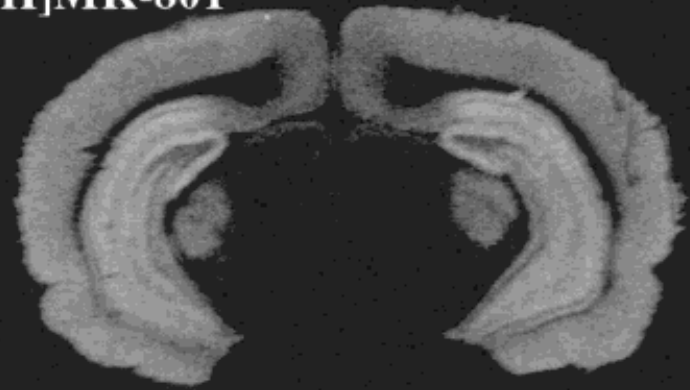

Fig. 1. Distribution of NMDA receptor subunit mRNAs and binding sites in the rat hippocampus. R2C subunit mRNA levels were not consistently above background. 


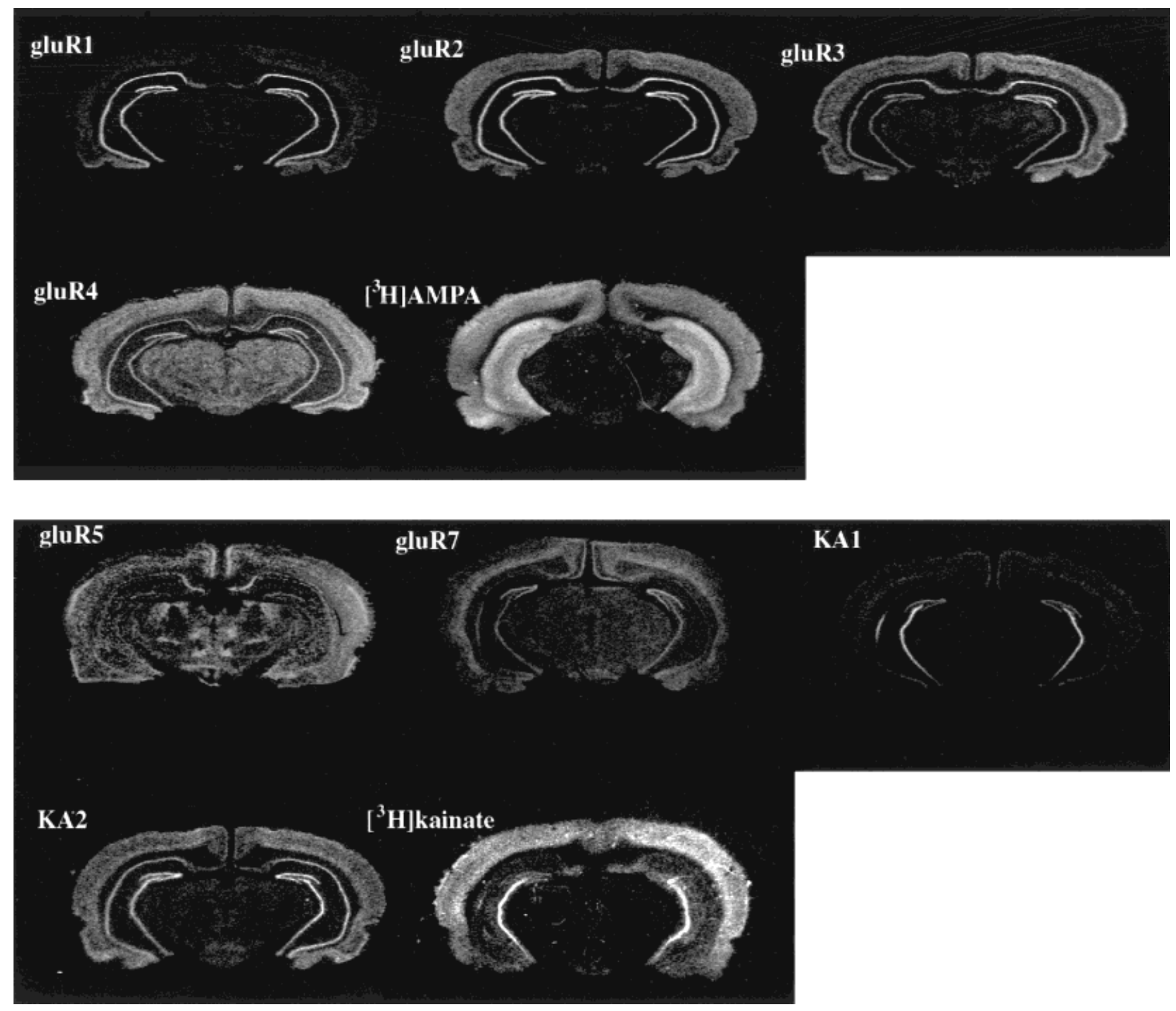

Fig. 2. Distribution of AMPA and kainate receptor subunit mRNAs and $\left[{ }^{3} \mathrm{H}\right] \mathrm{AMPA}$ and $\left[{ }^{3} \mathrm{H}\right]$ kainate binding sites in the rat hippocampus. GluR6 subunit mRNA levels were not consistently above background.

0.05). Further, there was a significant treatment by duration interaction for the expression of this binding site $\left(\mathrm{F}_{6,36}=3.97 ; P<0.005\right)$; acute high dose MK-801 treatment differed from acute and 5 -day low dose treatment, while 5-day control treatment differed from acute and 5-day low dose treatment (all $P<0.05$ ). There was a main effect for treatment on $\left[{ }^{3} \mathrm{H}\right] \mathrm{CGP} 39653$ binding $\left(\mathrm{F}_{2,12}=3.47 ; P<0.05\right)$, with low dose MK-801 treatment significantly differing from high dose and control (both $P<0.05)$. There were no significant differences for $\left[{ }^{3} \mathrm{H}\right] \mathrm{MDL} 105,519$ binding.

\section{Kainate receptor regulation}

There was no main effect for treatment on any of the five subunit mRNAs, nor were there any signifi- cant interactions. There was no main effect of treatment on $\left[{ }^{3} \mathrm{H}\right]$ kainate binding, although there was a significant treatment by region interaction $\left(\mathrm{F}_{6,24}=\right.$ $2.57 ; P<0.05$ ) (these data are not presented graphically).

\section{AMPA receptor regulation}

There was no main effect for treatment on any of the four subunit mRNAs, although there were significant treatment by duration $\left(\mathrm{F}_{6,24}=3.08 ; P<0.05\right)$ and treatment by region $\left(\mathrm{F}_{8,32}=3.91 ; P<0.005\right)$ interactions for gluR4 expression (data not shown). $\left[{ }^{3} \mathrm{H}\right] \mathrm{AMPA}$ binding expression was not affected by either treatment (these data are not presented graphically). 


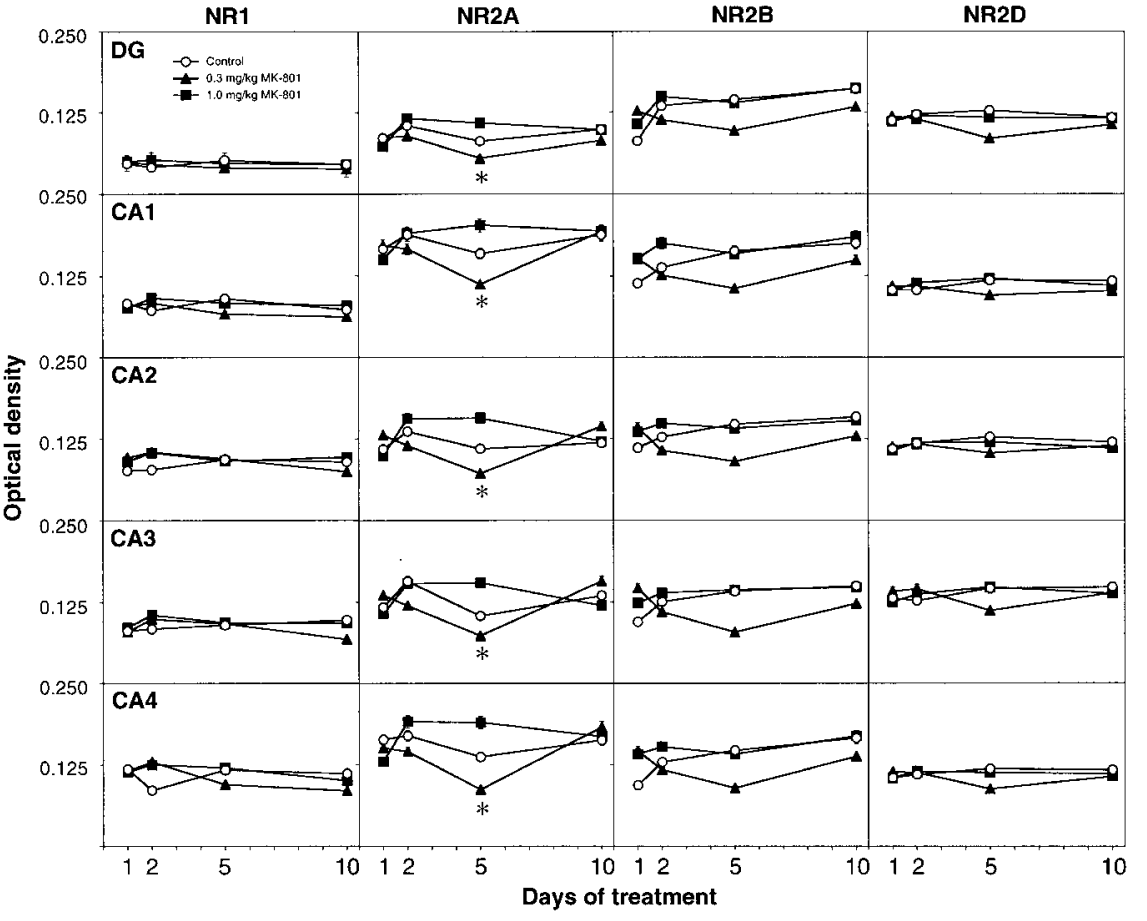

Fig. 3. The effects of $1,2,5$, or 10 daily injections of MK-801 on NMDA receptor subunit mRNA levels in the dentate gyrus and hippocampus. Data are expressed as optical density \pm SEM for five animals. There was no main effect for treatment on any of the four subunit mRNAs. There was a significant treatment by duration interaction for NR2A, and post-hoc analysis revealed that low dose MK-801 treatment differed from high dose $(* P<0.05)$. Film exposure times varied for each probe and binding site, so direct comparisons of optical density values between probes or binding sites should not be made.

\section{Experiment 2 (AMPA/kainate receptor modulators) \\ NMDA receptor regulation}

There was a main effect for treatment for NR2B mRNA levels $\left(\mathrm{F}_{5,53}=13.47 ; P<0.0001\right)$ (Fig. 5). Posthoc analysis revealed that aniracetam, CNQX, and GYKI52466 treatments each differed from control (all $P<0.05$ ). For all five treatments, there were signifi- cant treatment by region interactions $\left(\mathrm{F}_{20,212}=20.49\right.$; $P<0.0001$ ) for NR2B mRNA expression (Fig. 5). No other subunit mRNA was significantly affected by the treatments in this experiment. There were several significant findings for NMDA receptor binding sites in this experiment. There was a main effect for treatment on $\left[{ }^{3} \mathrm{H}\right] \mathrm{MK}-801$ binding $\left(\mathrm{F}_{5,53}=24.66 ; P<0.0001\right)$; post-hoc tests demonstrated that all five treatments

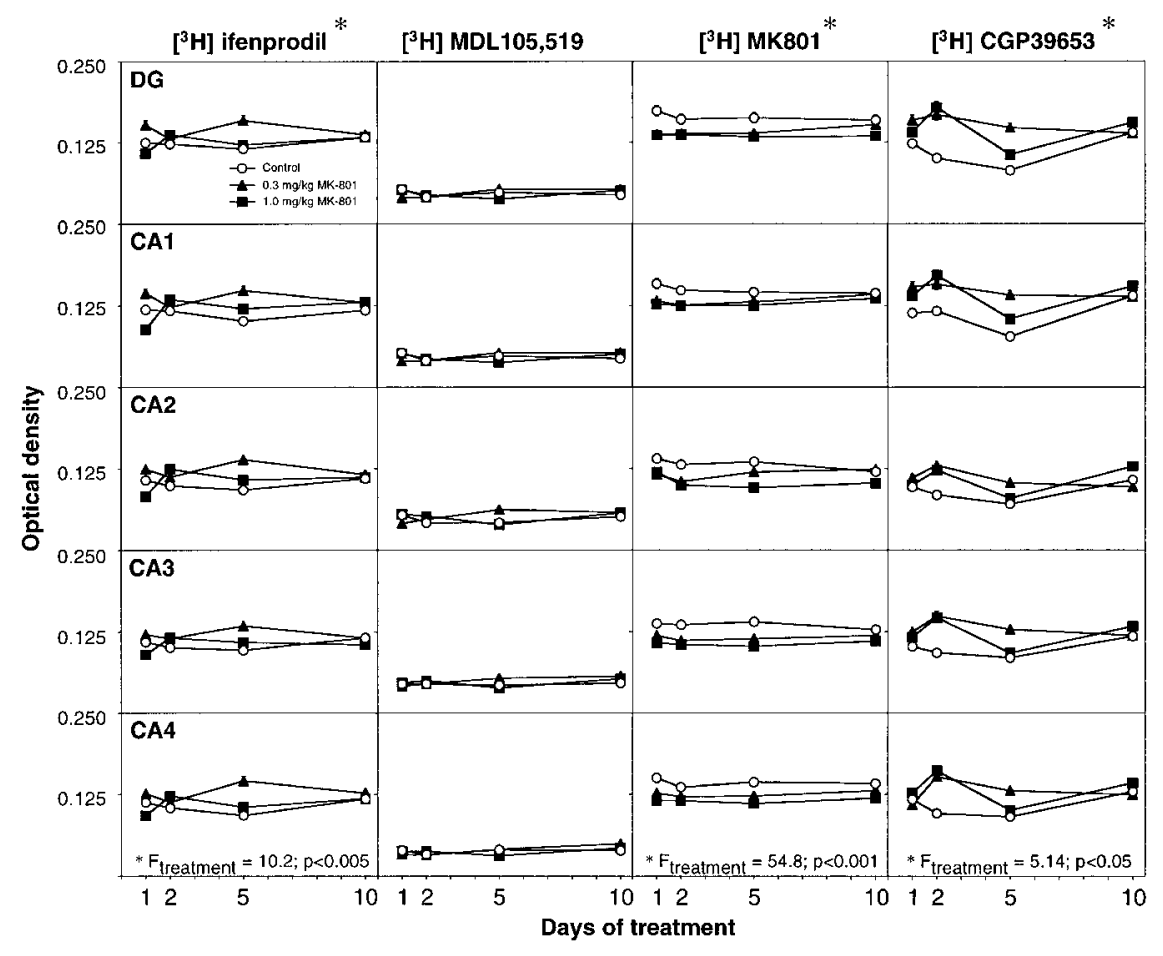

Fig. 4. The effects of $1,2,5$, or 10 daily injections of MK-801 on NMDA receptor binding site levels in the dentate gyrus and hippocampus. Data are expressed as optical density \pm SEM for five animals. There was a main effect for treatment on $\left[{ }^{3} \mathrm{H}\right]$ ifenprodil binding, with low dose MK-801 treatment significantly differing from high dose and control (both $P<0.05$ ). There were no significant differences for $\left[{ }^{3} \mathrm{H}\right] \mathrm{MDL} 105,519$ binding. $\left[{ }^{3} \mathrm{H}\right] \mathrm{MK}-801$ binding was significantly decreased by MK-801 treatment. Post-hoc tests demonstrated that both doses of MK801 differed from control (both $P<0.001$ ), as well as from each other $(P<0.05)$. There was a main effect for treatment on $\left[{ }^{3} \mathrm{H}\right] \mathrm{CGP} 39653$ binding $\left(\mathrm{F}_{212}=3.47 ; P<0.05\right)$, with low dose MK-801 treatment significantly differing from high dose and control (both $P<0.05$ ). Film exposure times varied for each probe and binding site, so direct comparisons of optical density values between probes or binding sites should not be made. 
Fig. 5. The effects of seven daily injections of aniracetam (A), CNQX (C), GYKI52466 (G), NBQX (N), or riluzole $(\mathbf{R})$ on NMDA receptor expression in the dentate gyrus and hippocampus. Data are expressed as percent change from control \pm SEM for 10 animals. *Significantly different from control $(P<0.05)$.

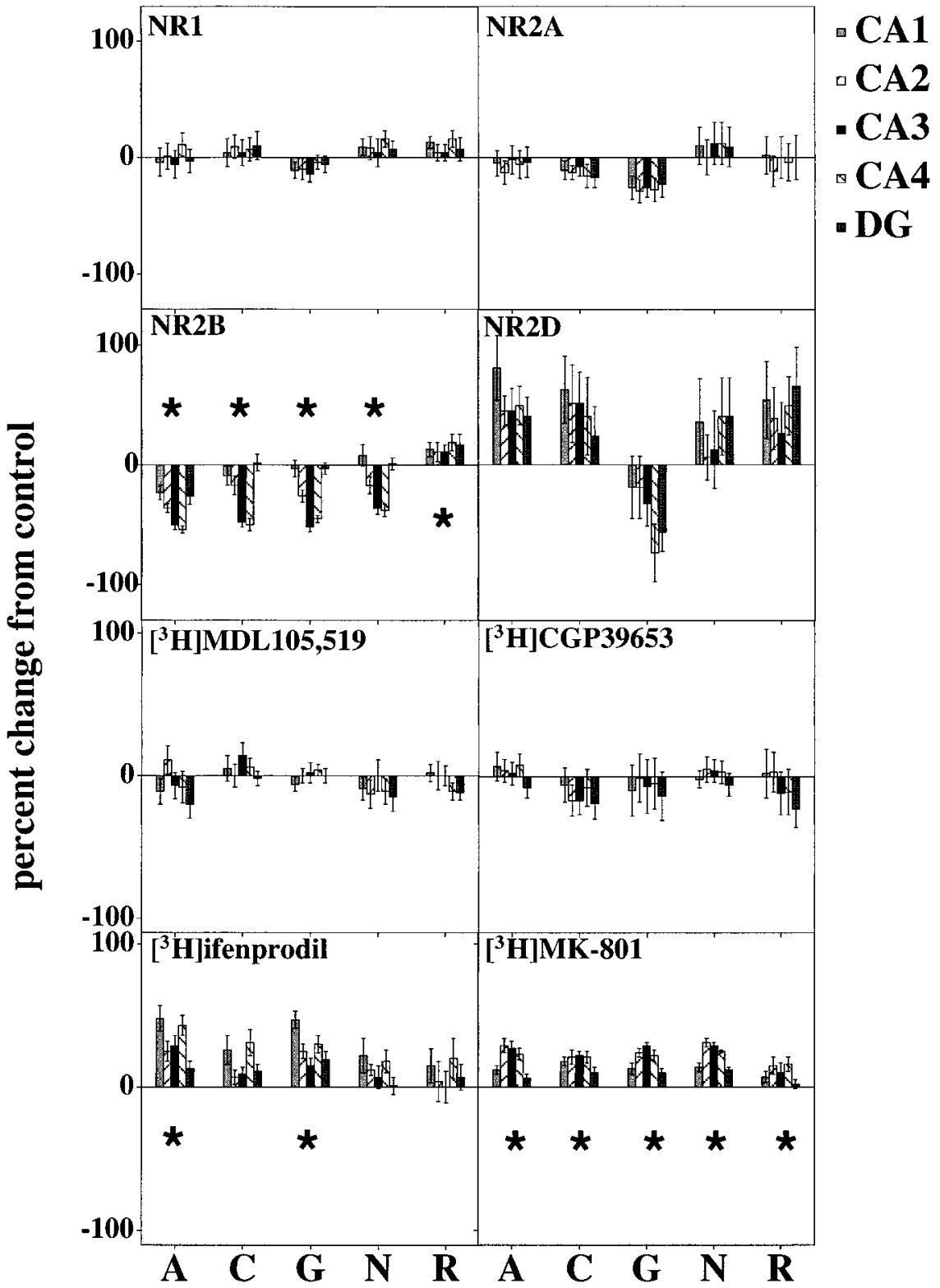

induced significant increases (all $P<0.01$ ), compared to vehicle. There was a main effect for treatment on $\left[{ }^{3} \mathrm{H}\right]$ ifenprodil binding $\left(\mathrm{F}_{5,53}=8.50 ; P<0.0001\right)$, with aniracetam $(P<0.0001)$ and GYKI52466 $(P<0.005)$ treatments significantly differing from control. There were no significant differences for $\left[{ }^{3} \mathrm{H}\right] \mathrm{CGP} 39653$ or $\left[{ }^{3} \mathrm{H}\right] \mathrm{MDL} 105,519$ binding.

\section{Kainate receptor regulation}

There was a main effect for treatment for each of the three low affinity kainate receptor subunit mRNAs (gluR5: $\mathrm{F}_{5,53}=5.50 ; P<0.0001$; gluR6: $\mathrm{F}_{5,53}=6.53$; $P<0.0001$; gluR7: $\mathrm{F}_{5,53}=3.56 ; P<0.005$ ). Post-hoc analysis showed that aniracetam treatment caused a significant decrease in gluR5 mRNA $(P<0.005)$ and a significant increase in gluR7 mRNA $(P<0.05)$, relative to control, while NBQX treatment resulted in a significant increase in gluR7 mRNA $(P<0.05)$. None of the five treatments caused significant alterations in gluR6 mRNA levels, relative to control. There was no main effect for treatment on KA1 and KA2, but there was a significant main effect for $\left[{ }^{3} \mathrm{H}\right]$ kainate binding $\mathrm{F}_{5,53}=$ 4.38; $P<0.001$ ). However, none of the five treatments caused significant alterations in $\left[{ }^{3} \mathrm{H}\right]$ kainate binding relative to control. There were no significant treatment by region interactions for any markers of kainate receptor expression.

\section{AMPA receptor regulation}

There was no main effect for treatment on any of the four subunit mRNAs or $\left[{ }^{3} \mathrm{H}\right]$ AMPA binding, except for a significant main effect for treatment on gluR1 mRNA 
levels $\left(\mathrm{F}_{5,53}=5.01 ; P<0.0005\right)$; NBQX treatment caused a significant decrease in this subunit mRNA $(P<0.05)$ (neither these AMPA nor kainate data are shown graphically).

\section{DISCUSSION}

NMDA receptor expression was more sensitive to regulation in these experiments than either AMPA or kainate receptors, even by direct antagonists of nonNMDA ionotropic receptors. However, the regulation of NMDA receptor expression was limited to one subunit mRNA and two binding sites, suggesting that there is selectivity in the effects.

All five drugs in Experiment 2 caused an upregulation of $\left[{ }^{3} \mathrm{H}\right] \mathrm{MK}-801$ binding, while MK-801 treatment caused a downregulation. In our studies, we were not able to detect whether the change in binding reflected a change in total number of receptors or a change in affinity. The lack of a concomitant decrease in glycine or glutamate binding in either experiment argues against a change in total receptor number. There are several potential mechanisms for a change in PCP site affinity. For example, the NR1 subunits containing exon 5 have been shown to have higher affinity for $\left[{ }^{3} \mathrm{H}\right] \mathrm{MK}-801$ (Rodriguez-Paz et al., 1995), so perhaps a downward shift in exon 5-containing NR1 subunits resulted from MK-801 treatment, and/or an upward shift is associated with the treatments in Experiment 2 . Because we measured total NR1 mRNA, the present study could not detect these changes. Alternatively, PCP site affinity decreases with the inclusion of NR2C or NR2D subunits, in place of NR2A or NR2B (Lynch et al., 1994); perhaps there was a shift in receptor composition not detectable at the level of mRNA expression. Less likely is the possibility that residual MK-801 was not washed off during receptor autoradiography in Experiment 1 and competed with $\left[{ }^{3} \mathrm{H}\right] \mathrm{MK}-801$. However, sections were washed under conditions that open NMDA receptor ion channels, which allows for the dissociation of residual MK-801 prior to the addition $\left[{ }^{3} \mathrm{H}\right] \mathrm{MK}-801$ (Huettner and Bean, 1988). Further, there was no difference between the low and high dose animals, which might be expected if residual MK-801 was competing with $\left[{ }^{3} \mathrm{H}\right] \mathrm{MK}-801$.

Similarly, the increases in both $\left[{ }^{3} \mathrm{H}\right]$ ifenprodil binding and $\left[{ }^{3} \mathrm{H}\right] \mathrm{MK}-801$ binding seen in Experiment 2 may be parsimoniously explained by an increase in NR2B incorporation into final assembled receptors, but only if the previous population contained proportionately more NR2C or NR2D. A shift toward NR2B from NR2C or NR2D would not only increase the affinity of NMDA receptors for MK-801 (as manifested by an increase in $\left[{ }^{3} \mathrm{H}\right] \mathrm{MK}-801$ binding) (Lynch et al., 1994), but would also increase affinity for ifenprodil (Williams, 1997). Further, these NR2B-containing receptors might be more sensitive to the antipsychotic haloperidol (Ilyin et al., 1996); it is tempting to speculate that certain glu- tamatergic compounds may be used as an adjunct to antipsychotic treatment to alter the potency of antipsychotics at NMDA receptors. Conversely, a change in exon 5-containing NR1 subunit expression probably cannot account for changes in both $\left[{ }^{3} \mathrm{H}\right]$ ifenprodil and $\left[{ }^{3} \mathrm{H}\right] \mathrm{MK}-801$ binding. While the inclusion of this exon increases the affinity for MK-801 (Rodriguez-Paz et al., 1995), it actually decreases spermine potentiation in vitro (Durand et al., 1993). While ifenprodil apparently does not label the polyamine site, but rather a modulatory site of the polyamine site, it might still be expected that these receptors would have a lower affinity for ifenprodil (Gallagher et al., 1996; Legendre and Westbrook, 1991; Reynolds and Miller, 1989).

GYKI52466 and aniracetam treatments resulted in significant increases in $\left[{ }^{3} \mathrm{H}\right]$ ifenprodil binding; these drugs also caused a decrease in NR2B mRNA. The presence of this subunit in assembled NMDA receptors is associated with increased affinity for ifenprodil (Gallagher et al., 1996; Williams, 1997). If protein levels of NR2B are also decreased, then these data would be the opposite of what would be expected. Data for lower dose MK-801 treatment from Experiment 1 may clarify this result (Figs. 3, 4); $\left[{ }^{3} \mathrm{H}\right]$ ifenprodil binding peaks on day 5 and returns to baseline by day 10, while NR2B mRNA reaches its nadir at day 5 , but also returns to baseline by day 10 . This suggests that there is a posttranscriptional increase in NR2B protein synthesis, or increased inclusion of NR2B from the cytoplasmic pool into the final receptors; these processes may result in increased $\left[{ }^{3} \mathrm{H}\right]$ ifenprodil binding that peaks around 5 days. During the rise in $\left[{ }^{3} \mathrm{H}\right]$ ifenprodil binding, feedback mechanisms may occur at the transcriptional level that drive down $\left[{ }^{3} \mathrm{H}\right]$ ifenprodil binding by decreasing NR2B synthesis. By day 10 , both $\left[{ }^{3} \mathrm{H}\right]$ ifenprodil and NR2B mRNA levels are back to baseline. Obviously, NR2B protein levels and more time points would need to be measured to test this hypothesis, but it is one way to explain the dissociation between $\left[{ }^{3} \mathrm{H}\right]$ ifenprodil binding and NR2B mRNA levels seen for GYKI52466 and aniracetam treatments.

Aniracetam and GYKI52466 would not be expected to cause similar effects on glutamate receptor expression, given that they have opposite effects on AMPA receptor desensitization (Bleakman and Lodge, 1998). One recent study, however, suggests that aniracetam may have paradoxical effects that may depend on intrinsic hippocampal circuitry. Concomitant aniracetam treatment $(3-5 \mu \mathrm{M})$ prevented NMDA-induced hippocampal neurotoxicity in vitro (Pizzi et al., 1995), which does not appear to be due to a direct effect of aniracetam on the NMDA receptor (Martin and Haefely, 1993). This was unexpected, considering that the increased AMPA receptor activity putatively induced by aniracetam would be expected to exacerbate excitotoxicity. It is unclear whether the effects of aniracetam are mediated by presynaptic or postsynap- 
tic AMPA receptors, and perhaps our findings are related to differential effects of GYKI52466 and aniracetam on different populations of AMPA receptors (Patel and Croucher, 1997).

AMPA receptor expression was minimally affected, even by direct antagonists, at the levels of total subunit mRNA and $\left[{ }^{3} \mathrm{H}\right] \mathrm{AMPA}$ binding. NBQX, GYKI52466, and CNQX would all be expected to induce an upregulation of AMPA receptors, given their potent AMPA receptor antagonist properties. Perhaps the complex intrisinic circuitry of the hippocampus mitigates expected increases in AMPA receptor expression after antagonist treatment.

Similarly, kainate receptor expression was also only modestly affected. None of the five treatments in Experiment 2 altered $\left[{ }^{3} \mathrm{H}\right]$ kainate binding, while MK-801 induced only a significant treatment by region interaction (consistent with Gao and Tamminga, 1995). CNQX, the drug for which kainate receptors have the highest affinity in this study, did not significantly alter kainate receptor expression. Surprisingly, aniracetam had the greatest effect on kainate receptor expression. If mRNA levels reflect protein levels, then aniracetam may be inducing a shift in kainate receptor composition. GluR5 homomers in vitro are activated by glutamate but desensitize quickly (Sommer et al., 1992), while gluR7 homomers have been shown to display very low affinity for glutamate (Schiffer et al., 1997). The net effect of this shift from gluR5- to gluR7-containing receptors may be to make kainate receptors less responsive to glutamate. Kainate receptors have been shown to decrease GABAergic inhibition, so decreases in kainate receptor activity may result in a relative increase in GABAergic activity (Clarke et al., 1997; Frerking et al., 1998; Rodriguez-Moreno et al., 1997). Aniracetam presumably increases postsynaptic AMPA receptor activity, so the shift in kainate receptor expression may represent a feedback mechanism that increases GABAergic inhibition to prevent AMPA receptor-mediated hyperexcitability.

For the most part, GYKI52466, CNQX, and NBQX treatments produced similar patterns of glutamate receptor expression in hippocampus. This would suggest that these drugs have a common effect, namely, AMPA receptor antagonism. CNQX and NBQX both antagonize AMPA receptors by a different mechanism than GYKI52466, which may explain some subtle differences between the effects of these drugs.

Aniracetam was the only positive modulator in either experiment, and seemed to induce the most dramatic effects on NMDA and kainate receptor expression. This might suggest that glutamatergic hyperactivity is a stronger impetus than hypoactivity to regulate glutamate receptor expression. Again, it is surprising that these putative feedback mechanisms did not affect AMPA receptor expression. Alternatively, aniracetam may have exerted its effects through a cholinergic mechanism
(Pepeu and Spignoli, 1989). However, seven daily injections of the acetylcholinesterase inhibitor tacrine resulted in decreased hippocampal AMPA receptor expression, but no change in kainate or NMDA receptor expression (Sihver et al., 1997). These results are in direct contrast to our data, strongly arguing against a cholinergic mechanism for the effects of aniracetam in our study.

Hippocampal NMDA receptor expression was more sensitive to regulation than AMPA and kainate receptors expression, even by direct AMPA and kainate receptor antagonists. Our data suggest that ionotropic glutamate receptors interact at the level of receptor expression; there may be common adaptive mechanisms, associated with changes in NMDA receptor expression, that result from altered glutamatergic activity. These adaptions may be useful for the design of novel therapies for dementias, epilepsy, and schizophrenia. Conversely, these data also suggest that drug regimens that attempt to target one ionotropic glutamate receptor subtype may indirectly affect other subtypes, potentially producing unwanted side effects.

\section{ACKNOWLEDGMENTS}

Dr. Healy was an American Psychiatric Association/ Lilly Psychiatric Research Fellow during the performance of this study. Portions of this work were presented at the 37th Annual Meeting of the American College of Neuropsychopharmacology, Las Croabas, Puerto Rico, December 1998. We thank Alan Hogg for assistance in preparing the manuscript.

\section{REFERENCES}

Baron BM, Siegel BW, Harrison BL, Gross RS, Hawes C, Towers P. 1996. $\left[{ }^{3} \mathrm{H}\right] \mathrm{MDL} 105,519$, a high-affinity radioligand for the $\mathrm{N}-\mathrm{meth}$ yl-D-aspartate receptor-associated glycine recognition site. J Pharmacol Exp Ther 279:62-68.

Bleakman D, Lodge D. 1998. Neuropharmacology of AMPA and kainate receptors. Neuropharmacology 37:1187-1204.

Clarke VRJ, Ballyk BA, Hoo KH, Mandelzys A, Pellizzari A, Bath CP, Thomas J, Sharpe EF, Davies CH, Ornstein PL, Schoepp DD, Kamboj RK, Collingridge GL, Lodge D, Bleakman D. 1997. A hippocampal gluR5 kainate receptor regulating inhibitory synaptic transmission. Nature 389:599-603.

Durand GM, Bennett MVL, Zukin RS. 1993. Splice variants of the N-methyl-D-aspartate receptor NR1 identify domains involved in regulation by polyamines and protein kinase C. Proc Natl Acad Sci USA 90:6731-6735.

Frerking M, Malenka RC, Nicoll RA. 1998. Synaptic activation of kainate receptors on hippocampal interneurons. Nat Neurosci 1:479-486.

Gallagher MJ, Huang H, Pritchett DB, Lynch DR. 1996. Interactions between ifenprodil and the NR2B subunit of the N-methyl-D-aspartate receptor. J Biol Chem 271:9603-9611.

Gao X-M, Tamminga CA. 1995. MK-801 induces late regional increases in NMDA and kainate receptor binding in rat brain. J Neural Trans 101:105-113.

Gao X-M, Tamminga CA. 1996. Phencyclidine produces changes in NMDA and kainate receptor binding in rat hippocampus over a 48-hour time course. Synapse 23:274-279.

Hashimoto K, Mantione CR, Spada MR, Neumeyer JL, London ED. 1994. Further characterization of $\left[{ }^{3} \mathrm{H}\right]$ ifenprodil binding in rat brain. Eur J Pharmacol 266:67-77.

He Y, Janssen WGM, Morrison JH. 1998. Synaptic coexistence of AMPA and NMDA receptors in the rat hippocampus: a postembedding immunogold study. J Neurosci Res 54:444-449.

Healy DJ, Meador-Woodruff JH. 1996. Differential regulation, by MK-801, of dopamine receptor gene expression in rat nigrostriatal and mesocorticolimbic systems. Brain Res 708:38-44. 
Healy DJ, Haroutunian V, Powchik P, Davidson M, Davis KL, Watson SJ, Meador-Woodruff JH. 1998. AMPA receptor binding and subunit mRNA expression in prefrontal cortex and striatum of elderly schizophrenics. Neuropsychopharmacology 19:278-286.

Himori N, Suzuki T, Ueno K. 1995. Aniracetam, a pyrrolidinone-type cognition enhancer, attenuates the hydroxyl free radical formation in the brain of mice with brain ischaemia. J Pharm Pharmacol 47:253-8.

Hollmann M, Heinemann S. 1994. Cloned glutamate receptors. Annu Rev Neurosci 17:31-108.

Huettner JE, Bean BP. 1987. Block of N-methyl-D-aspartate-activated current by the anticonvulsant MK-801: selective binding to open channels. Proc Natl Acad Sci USA 85:1307-1311.

Ilyin VI, Whittemore ER, Guastella J, Weber E, Woodward RM. 1996. Subtype-selective inhibition of N-methyl-D-aspartate receptors by haloperidol. Mol Pharmacol 50:1541-1550.

Legendre P, Westbrook GL. 1991. Ifenprodil blocks N-methyl-D-aspartate receptors by a two component mechanism. Mol Pharmacol 40:289-298.

Lissin DV. Gomperts SN, Carroll RC, Christine CW, Kalman D, Kitamura M, Hardy S, Nicoll RA, Malenka RC, von Zastrow M. 1998. Activity differentially regulates the surface expression of synaptic AMPA and NMDA glutamate receptors. Proc Natl Acad Sci 95:7097-7102.

Lynch DR, Anegawa NJ, Verdoorn T, Pritchett DB. 1994. N-methylD-aspartate receptors: Different subunit requirements for binding of glutamate antagonists, glycine antagonists, and channel-blocking agents. Mol Pharmacol 45:540-545.

Malgouris C, Bardot F, Daniel M, Pellis F, Rataud J, Uzan A, Blanchard JC, Laduron PM. 1989. Riluzole, a novel antiglutamate, prevents memory loss and hippocampal neuronal damage in ischemic gerbils. J Neurosci 9:3720-7.

Martin JR, Haefely WE. 1993. Pharmacology of aniracetam, a novel pyrrolidinone derivative with cognition enhancing activity. Drug Invest 5(Suppl. 1):4-9.

Mead AN, Stephens DN. 1998. AMPA-receptors are involved in the expression of amphetamine-induced behavioural sensitization, but not in the expression of amphetamine-induced conditioned activity in mice. Neuropharmacology 37:1131-1138.

Meador-Woodruff JH, King RE, Damask SP, Bovenkerk KA. 1997. Differential regulation of hippocampal AMPA and kainate receptor subunit expression by haloperidol and clozapine. Mol Psychiatry $1: 41-53$.

Monaghan DT, Cotman CW. 1982. Distribution of $[3 \mathrm{H}] \mathrm{kainic}$ acid sites in rat CNS as determined by autoradiography. Brain Res 252:91-100.

Nielsen EO, Cha J-HJ, Honore T, Penney JB, Young AB. 1988. Thiocyanate stabilizes AMPA binding to the quisqualate receptor. Eur J Pharmacol 157:197-203.

Patel DR, Croucher MJ. 1997. Evidence for a role of presynaptic AMPA receptors in the control of neuronal glutamate release in the rat forebrain. Eur J Pharmacol 332:143-151.

Paxinos G, Watson C. 1982. The rat brain in stereotactic coordinates. New York: Academic Press.
Pepeu G, Spignoli G. 1989. Nootropic drugs and brain cholinergic mechanisms. Prog Neuro-Psychopharmacol Biol Psychiatry 13(Suppl):S77-88.

Pizzi M, Consolandi O, Memo M, Spano P. 1995. N-Methyl-D-aspartate neurotoxicity in hippocampal slices: protection by aniracetam. Eur J Pharmacol 275:311-314.

Ransom RW, Stec NL. 1988. Cooperative modulation of $\left[{ }^{3} \mathrm{H}\right] \mathrm{MK}-801$ binding to the N-methyl-D-aspartate receptor-ion channel complex by L-glutamate, glycine, and polyamines. J Neurochem 51:830836.

Reynolds IJ, Miller RJ. 1989. Ifenprodil is a novel type of N-methylD-aspartate receptor antagonist: interaction with polyamines. Mol Pharmacol 36:758-765.

Rodriguez-Moreno A, Herreras O, Lerma J. 1997. Kainate receptors presynaptically downregulate GABAergic inhibition in the rat hippocampus. Neuron 19:893-901.

Rodriguez-Paz JM, Anantharam V, Treistman SN. 1995. Block of the $\mathrm{N}$-methyl-D-aspartate receptor by phencyclidine-like drugs is influenced by alternative splicing. Neurosci Lett 190:147-150.

Romettino S, Lazdunski M, Gottesmann C. 1991. Anticonvulsant and sleep-waking influences of riluzole in a rat model of absence epilepsy. Eur J Pharmacol 199:371-373.

Schiffer HH, Swanson GT, Heinemann SF. 1997. Rat gluR7 and a carboxy-terminal splice variant, gluR7b, are functional kainate receptor subunits with a low sensitivity to glutamate. Neuron 19: $1141-1146$.

Siegel BW, Sreekrishna K, Baron BM. 1996. Binding of the radiolabelled glycine site antagonist $\left[{ }^{3} \mathrm{H}\right] \mathrm{MDL} 105,519$ to homomeric NMDA-R1a receptors. Eur J Pharmacol 312:357-365.

Sihver W, Gunther P, Schliebs R, Bigl V. 1997. Repeated administration of tacrine to normal rats: effects on cholinergic, glutamatergic, and GABAergic receptor subtypes in rat brain using receptor autoradiography. Neurochem Int 31:693-703.

Sills MA, Fagg G, Pozza M, Angst C, Brundish DE, Hurt SD, Wilusz EJ, Williams M. 1991. $\left[{ }^{3} \mathrm{H}\right]$ CGP39653: a new N-methyl-D-aspartate antagonist radioligand with low nanomolar affinity in rat brain. Eur J Pharmacol 192:19-24.

Sommer B, Burnashev N, Verdoorn TA, Keinanen K, Sakmann B, Seeburg PH. 1992. A glutamate receptor channel with high affinity for domoate and kainate. EMBO J 11:1651-1656.

Vanover KE. 1998. Effects of AMPA receptor antagonists on dopamine-mediated behaviors in mice. Psychopharmacology 136:123-131.

Wahl F, Allix M, Plotkine M, Boulu RG. 1993. Effect of riluzole on focal cerebral ischemia in rats. Eur J Pharmacol 230:209-214.

Wheal HV, Thomson AM. 1995. Excitatory amino acids and synaptic transmission. London: Academic Press.

White BH, Vogel MW. 1996. CGP 39653 binding in the chick CNS after NMDA receptor antagonist treatment. J Neural Transm 103: $1247-1253$.

Williams K. 1997. Interactions of polyamines with ion channels. Biochem J 325:289-297.

Yamada K, Inoue T, Tanaka M, Furukawa T. 1985. Prolongation of latencies for passive avoidance responses in rats treated with aniracetam or piracetam. Pharmacol Biochem Behav 22:645-648. 